\title{
HOUSING TENURE PREFERENCES AMONG STUDENTS FROM TWO POLISH UNIVERSITIES
}

\author{
Michał Rubaszek \\ Warsaw School of Economics \\ e-mail:mrubas@sgh.waw.pl \\ Justyna Rubaszek \\ Wroclaw University of Environmental and Life Sciences \\ e-mail: justyna.rubaszek@upwr.edu.pl
}

\begin{abstract}
The housing rental market in Poland is underdeveloped and tilted towards temporary tenants, usually students and immigrants. To explore the flaws in the functioning of this market, we conduct a survey among 315 students from two Polish universities. We find that renting is not only perceived as a more expensive form of satisfying housing needs, but decreases satisfaction from utilizing the occupied house due to non-financial factors. Moreover, the perception of the relative advantages of owning versus renting is, to some extent, affected by flawed economic reasoning. Building on the above results, we discuss what policies could increase the demand for residential rental housing.
\end{abstract}

Key words: Housing tenure choice, household preferences, survey.

JEL Classification: C83; D91; O18, R21.

Citation: Rubaszek, M. \& Rubaszek, J. (2021). Housing tenure preferences among students from two polish universities. Real Estate Management and Valuation, 29(2), 71-83.

DOI: https://doi.org/10.2478/remav-2021-0014

\section{Introduction}

Food, shelter and clothing are commonly considered to be the main basic needs of human beings. This is why the role of housing cannot be overstated and decisions on how to satisfy housing needs are among the key economic choices made by households over their lifespan. The most popular form of satisfying these needs is ownership, where a house serves a dual purpose: it provides shelter and, at the same time, is an investment vehicle. For young adults, i.e., persons who are on the verge of making important choices related to family and work and who usually do not have their own capital, the affordability of ownership is limited by the fact that investing in a house requires financial wealth, support from the family or high creditworthiness combined with mortgage availability. This is why, for many young adults, renting, which does not require the upfront stock of savings, is often the only means of moving out of their parents' and living on their own. Consequently, the availability of rental housing has a serious impact on the dynamics of individual lives, including employment, family size or territorial mobility (Haurin et al. 1993; Barcelo, 2006; Caldera-Sanchez \& Andrews, 2011).

In the above context, the inefficient rental market observed in Poland should be considered as a serious sociological and economic problem. In this study, we address the topic by analyzing the attitudes of students towards both housing tenures. We do this by conducting an online survey, which is based on the recent work of Rubaszek and Czerniak (2017), among a group of 315 students from two universities. Our analysis is related to the recent article by Źróbek-Różańska (2019), who conducted a survey among students from Olsztyn, a medium-sized Polish city, to learn about their plans to stay in the city after graduation. She found that the rental market is a viable choice as over three-quarters of the respondents were planning to leave the city. We argue that the opinions of 
students about the functioning of the rental market is informative and provide value added in comparison to the results based on the representative sample for at least four reasons. Firstly, rental housing in Poland is predominantly occupied by students. Źróbek-Różańska and Szulc (2018) indicate that, each year, over a million students enter into tenancy agreements. Secondly, understanding the perception of young adults towards housing tenures is important as the availability of stable rental housing has a tremendous impact on their strategies of how to start living on their own. Thirdly, students are relatively mobile in comparison to the rest of the population and more often live in rented apartments. As a result, their opinion on the functioning of the rental market is more informative than the opinion of the part of the society which has always owned a house. Finally, students are relatively well educated, hence should be better prepared to evaluate the relative merits of owning and renting than the society as a whole. It should be emphasized, however, that the results of this study could also be treated with some reserve as the sample does not cover the entire population of young adults and is limited to people with higher educational attainment. We believe, however, that they are helpful in understanding the main obstacles for the rental housing demand in Poland as well as in other Central European countries.

The study contributes to three strands of literature. The first one explores the housing market developments in Central Europe after the collapse of the communist system, including the evolution of the rental market (Priemus \& Mandic, 2000; Lux \& Sunega, 2010a, 2010b, 2014; MuziołWęcławowicz, 2013; Vobecká et al. 2014; Rubaszek \& Rubio, 2020). The second one is more focused on factors that affect housing tenure choices, including economic and psychological factors (Henderson \& Ioannides, 1983; Coolen et al. 2002; Ben-Shahar, 2007; Drew \& Herbert, 2013; Rubaszek, 2019). The third one is related to survey studies regarding the housing preferences of Poles (Rubaszek \& Czerniak, 2017; Źróbek-Różańska, 2019; Palicki, 2020). We add to the above studies by showing that ownership is preferred to renting, predominantly because it is the only tenure that allows people to "feel at home". Moreover, we indicate that the perception of the relative advantages of both tenure forms is often driven by flawed reasoning.

The rest of the paper is organized as follows. In Section 2, we describe the history of rental market development in Poland. Section 3 presents the results of the survey. The implications for housing policy are presented in Section 4, whereas the last section concludes the work.

\section{Rental market development in Poland}

The size of the private rental market is very diverse across EU countries. According to Eurostat data in 2018, the fraction of "market price" tenants was the lowest in Romania (1.2\%), the highest in Germany $(40.8 \%)$, and, for all EU countries, stood at $22.0 \%$. According to Elsinga and Hoekstra (2005), heterogeneity in housing rental size can be explained by both institutional and cultural factors. For example, in the Anglo-Saxon countries, owning a house is usually associated with a sense of security, autonomy, personal identity and it is considered to be a sign of economic success. Consequently, a subjective utility from living in a dwelling that is owned is much higher than that derived from living in the same dwelling that is rented. This individual preference for homeownership is often reinforced by housing policy in the form of fiscal incentives to own, combined with a strong protection of tenants at the expense of landlords. In the case of German-speaking countries, the situation is different. The preference for ownership, both at the individual and country level, is not as strong as in other places in Europe. A sense of security is provided by a developed social system and strong protection of tenants, under which evictions or excessive rental price increases are limited. Moreover, fiscal support and good legislation encourage institutional investors to locate funds in residential real estate. This causes rental prices to be affordable, which allows people more freedom in choosing the time of entering into ownership. As regards Eastern European countries, they are characterized by a relatively tiny fraction of "market price" tenants, standing at levels well below $10 \%$. In Poland, which is the focus of our analysis and which can be considered to be a good representative of these countries, the detailed tenure structure in 2019 was as follows: "market price" tenants (4.2\%), "reduced price" tenant (11.6\%), owners (84.2\%).

Table 1

Characteristics of the respondents to the survey

\begin{tabular}{cccc}
\hline Sample & WSE & WUELS & Total \\
\hline & Age & & \\
\hline
\end{tabular}




\begin{tabular}{|c|c|c|c|}
\hline below 21 & 7.3 & 2.4 & 5.3 \\
\hline $21-24$ & 90.7 & 85.3 & 88.7 \\
\hline 25 or more & 2.1 & 12.3 & 6.0 \\
\hline \multicolumn{4}{|c|}{ Sex } \\
\hline Male & 46.1 & 29.5 & 39.7 \\
\hline Female & 53.9 & 70.5 & 60.3 \\
\hline \multicolumn{4}{|c|}{ Place of residence during childhood } \\
\hline Different country & 6.7 & 4.1 & 5.7 \\
\hline Different town in Poland & 62.2 & 59 & 61.0 \\
\hline The same city & 31.1 & 36.8 & 33.4 \\
\hline \multicolumn{4}{|c|}{ Marital status } \\
\hline Single & 94.3 & 96.7 & 95.2 \\
\hline Living with a partner & 5.7 & 3.3 & 4.8 \\
\hline \multicolumn{4}{|c|}{ Subjective view on economic situation (1-very bad, 10-very good) } \\
\hline $1-5$ & 9.3 & 39.2 & 20.9 \\
\hline $6-7$ & 45.6 & 34.0 & 41.0 \\
\hline $8-9$ & 45.1 & 26.6 & 38.1 \\
\hline \multicolumn{4}{|c|}{ Housing tenure status } \\
\hline Owner with a mortgage & 7.3 & 7.4 & 7.3 \\
\hline Owner without mortgage & 28.5 & 2.5 & 18.4 \\
\hline Tenant & 34.7 & 53.2 & 44.5 \\
\hline Campus dormitory & 4.7 & 8.2 & 6.0 \\
\hline Living with parents & 20.7 & 28.7 & 23.8 \\
\hline \multicolumn{4}{|c|}{ Duration of stay in current dwelling } \\
\hline Below 5 years & 67.9 & 67.2 & 67.6 \\
\hline Above 5 years & 15.0 & 9 & 12.7 \\
\hline Since childhood & 17.1 & 23.8 & 19.7 \\
\hline \multicolumn{4}{|c|}{ Plans to change the dwelling } \\
\hline No & 6.7 & 7.4 & 7.0 \\
\hline Yes, within 5 years & 80.8 & 73.8 & 78.1 \\
\hline Yes, after 5 years & 8.3 & 8.2 & 8.3 \\
\hline Don't know & 4.1 & 10.7 & 6.7 \\
\hline Number of observations & 193 & 122 & 315 \\
\hline
\end{tabular}

Notes: WSE and WUELS stand for Warsaw School of Economics and Wrocław University of Environmental and Life Sciences, respectively

Source: The survey.

This high proportion of owners and a marginal share of tenants in Poland can be explained by a number of factors. As indicated by Lux and Sunega $(2010 \mathrm{~b}, 2014)$, the declining trend in the rental market share in the group of Central European countries can be partly attributed to the transfer of public rental housing into private hands, which took the form of a massive sale to sitting tenants. This is well illustrated by the Eurostat data, according to which the share of public rental in Poland decreased from $34.9 \%$ in 2007 to just $11.6 \%$ in 2019 . The second factor is related to changes in the mortgage market, in particular a steady decrease of inflation and nominal interest rates, which often stood at two digit levels in the 1990s, combined with better access to FX denominated loans, including Swiss francs. Changes in the financial sector, but also a variety of programs enhancing house purchases on credit, led to an increase in the proportion of owners with a mortgage (from $2.9 \%$ in 2007 to $12.2 \%$ in 2019). Thirdly, there was a lack of consistent housing policy to develop the rental market. Even though there was a TBS program aimed at increasing the number of affordable rental housing in years 1996-2009, its success was limited due to insufficient support from the public sector (Muzioł-Węcławowicz, 2013), much lower than that within the two programs subsidizing mortgages. All the above factors are nicely summarized by Priemus and Mandic (2000), who claim (as indicated by the title of their article) that, in the countries of the region, both the private and public rental market at the beginning of the twenty-first century was "no man's land." In the case of the private 


\section{S sciendo}

rental market, one could observe a lack of institutional investors specializing in professional rental services. The authors indicate that the private rental market was de facto the extension of the ownership, in which the offer is dominated by dwellings uninhabited by the owner (i.e. inherited), not "buy-to-let" dwellings.

\section{Survey results}

The survey builds on the recent work of Rubaszek and Czerniak (2017), who asked a representative group of 1005 Poles about their attitudes towards owning and renting. We use the questionnaire of Rubaszek and Czerniak, which -translated into English - is presented in the Appendix, and conducted an online survey among 315 students from two Polish universities: Warsaw School of Economics (WSE, 193 respondents in Jan. 2017 and Jan. 2018) and Wrocław University of Environmental and Life Sciences (WUELS, 122 respondents in May 2017). The replies to the survey are discussed in the below subsections.

\subsection{Characteristics of the respondents}

We start by presenting the profile of both universities. They are located in large Polish cities: Warsaw (1.8 mln inhabitants) and Wrocław (0.6 mln inhabitants) and are considered among the most recognized universities in their disciplines in Poland. In the case of the WSE this is economics, whereas the WUELS is renowned for agriculture. The WSE is well known for its educational program tailored to market needs, whereas the WUELS is recognized for its innovative activity.

It can be claimed that the different profiles of the universities have an impact on the rationality of economic decisions, including those that are related to the topic of our study: housing tenure choices. The reasons are twofold. Firstly, economic universities tend to attract people who are interested in taking rational decisions (selection stage). Secondly, the curriculum of economic universities is oriented towards teaching students how to make rational decisions (education stage). The different profiles of both Universities also have an impact on other characteristics of students, such as sex, labor market activity or wealth. As indicated in Table 1, WSE were slightly younger and wealthier, as the replies to the question regarding the subjective view on the students' own economic situation would suggest. The higher material situation of WSE students is confirmed by the structure of responses about the tenure structure, which indicates that over a third of WSE respondents are homeowners compared to only $10 \%$ of WUEL ones. As regards questions about the marital status or migration activity, the responses were largely comparable. The table also indicates that the residential mobility of students of the two universities is comparable. About two-thirds of them moved into the currently inhabited dwelling within the last 5 years $(67.6 \%)$, and about three quarters of them plan to change the place of their residence within the next five years $(78.1 \%)$. The above numbers confirm that the respondents to our survey constitute a group of people entering the housing market, for whom the affordability of the rental market might affect decisions regarding their professional career or family size.

\subsection{Attitudes towards housing tenures}

The next block of survey questions was aimed at understanding the attitude of students towards both housing tenures. Before looking at the answers to these questions, let us mention two articles showing that people usually derive higher utility from living in an owned house rather than a rented one. In the first one, Elsinga and Hoekstra (2005) find that the legal status of an inhabited dwelling significantly affects the answer to the European Community Household Survey (ECHS) question: How satisfied are you with your housing situation? In the second one, Diaz-Serrano (2009) shows that the ECHS housing satisfaction index is significantly increased by the sole fact of changing the tenure status from renting to ownership, even without changing the place of residence. To check whether the respondents to our survey prefer ownership to renting and to measure how strong this preference is, we have asked few questions, the answers to which are presented in Table 2.

The first question was to compare buying a house (without a mortgage) to renting it in terms of a life-cycle investment decision (upper panel of Table 2). The respondents could choose the following alternatives:

a. Buying a house makes more sense because you're protected against rent increases and it is a good investment decision over the life cycle. 
b. Renting makes more sense because it enables flexibility and financial liquidity as well as protection against house price declines and, considering financial considerations, is a better deal than owning.

Answer a. was chosen by $78.7 \%$ of students, which compares to $87 \%$ of US respondents to the Fannie Mae National Housing Survey (Drew and Herbert 2013). This means that most of the respondents plan to become homeowners in the future. Next, we have checked if this decision is entirely based on rational calculations or if it is influenced by flawed economic reasoning. We have therefore asked the students if they agree with the following statement:

Buying a dwelling is financially better than renting it because after repaying the mortgage you are left with a dwelling and after paying rents you are left with nothing.

As indicated by Ben-Shahar (2007) this statement is false, as the evaluation of relative financial attractiveness of the two tenure forms should be based on the comparison of their present value. It turns out that as many as $81.6 \%$ of students agree with this statement, as compared to $85 \%$ in a survey among Israeli students (Ben-Shahar 2007). It is worth noticing that there are differences in the distribution of answers between the analyzed universities, which could indicate that WSE students base their answers on a more complex consideration.

Table 2

Attitudes towards housing tenure

\begin{tabular}{|c|c|c|c|}
\hline Sample & WSE & WUELS & TOTAL \\
\hline \multicolumn{4}{|c|}{ A sentence closer to your opinion } \\
\hline Buying makes more sense as it is a good investment & 73.1 & 87.7 & 78.7 \\
\hline Renting is better as it enables financial liquidity & 26.9 & 12.3 & 21.3 \\
\hline \multicolumn{4}{|c|}{$\begin{array}{l}\text { Buying a house is financially better than renting it because after repaying the mortgage you are } \\
\text { left with a house and after paying rents you are left with nothing }\end{array}$} \\
\hline Agree & 79.3 & 85.2 & 81.6 \\
\hline Don't agree & 11.9 & 6.6 & 9.8 \\
\hline No opinion & 8.8 & 8.2 & 8.6 \\
\hline \multicolumn{4}{|c|}{ Tenure choice if buying a dwelling is more expensive than renting } \\
\hline Buying & 29.5 & 36.1 & 32.0 \\
\hline Renting & 53.4 & 43.5 & 49.5 \\
\hline Don't know & 17.1 & 20.5 & 18.4 \\
\hline \multicolumn{4}{|c|}{ Paying rent is a waste of money } \\
\hline Agree & 34.2 & 39.4 & 36.1 \\
\hline Don't agree & 46.1 & 36.1 & 42.2 \\
\hline No opinion & 19.7 & 24.6 & 21.6 \\
\hline \multicolumn{4}{|c|}{ Tenure choice in case of no funds to buy a dwelling from savings } \\
\hline Buying despite the burden of a mortgage & 34.7 & 45.9 & 39.0 \\
\hline Renting & 48.7 & 30.3 & 41.6 \\
\hline Don't know & 16.6 & 23.8 & 19.4 \\
\hline Number of observations & 193 & 122 & 315 \\
\hline
\end{tabular}

Source: The survey.

The next two questions were aimed at checking if there are explicit non-financial factors that have an impact on tenure preferences. First, the students could declare their preferred tenure if owning is more expensive than renting. It turns out that $32.0 \%$ of respondents are eager to pay additional money to be a homeowner, whereas $49.5 \%$ of them would prefer to rent. Secondly, they could agree with the sentence that paying rent is a waste of money. In this case $36.1 \%$ of the respondents gave a positive answer. This shows that, for a large fraction of survey participants, there are other, non-financial factors, which have a significant impact on housing tenure decisions.

The last question focused on the views of respondents on both tenures in a longer horizon and was related to a choice between taking a mortgage and renting. Here the answers are relatively balanced: 


\section{$S$ sciendo}

for the entire sample of students, $39.0 \%$ declared purchasing with a mortgage against $41.6 \%$ of them choosing to rent.

\subsection{Economic and psychological factors and housing tenure preferences}

Our earlier discussion suggests that there are both financial and non-financial factors that affect housing tenure choices. To investigate this topic, we have asked a series of questions related to economic and psychological reasons to own or rent. As regards the former, basing on the literature, we have focused on the four following economic factors (Henderson \& Ioanides, 1983; Bourassa, 1995; Sinai \& Soueles, 2005):

- the relative cost of renting and paying off a mortgage,

- the risk of house price or rent fluctuations.

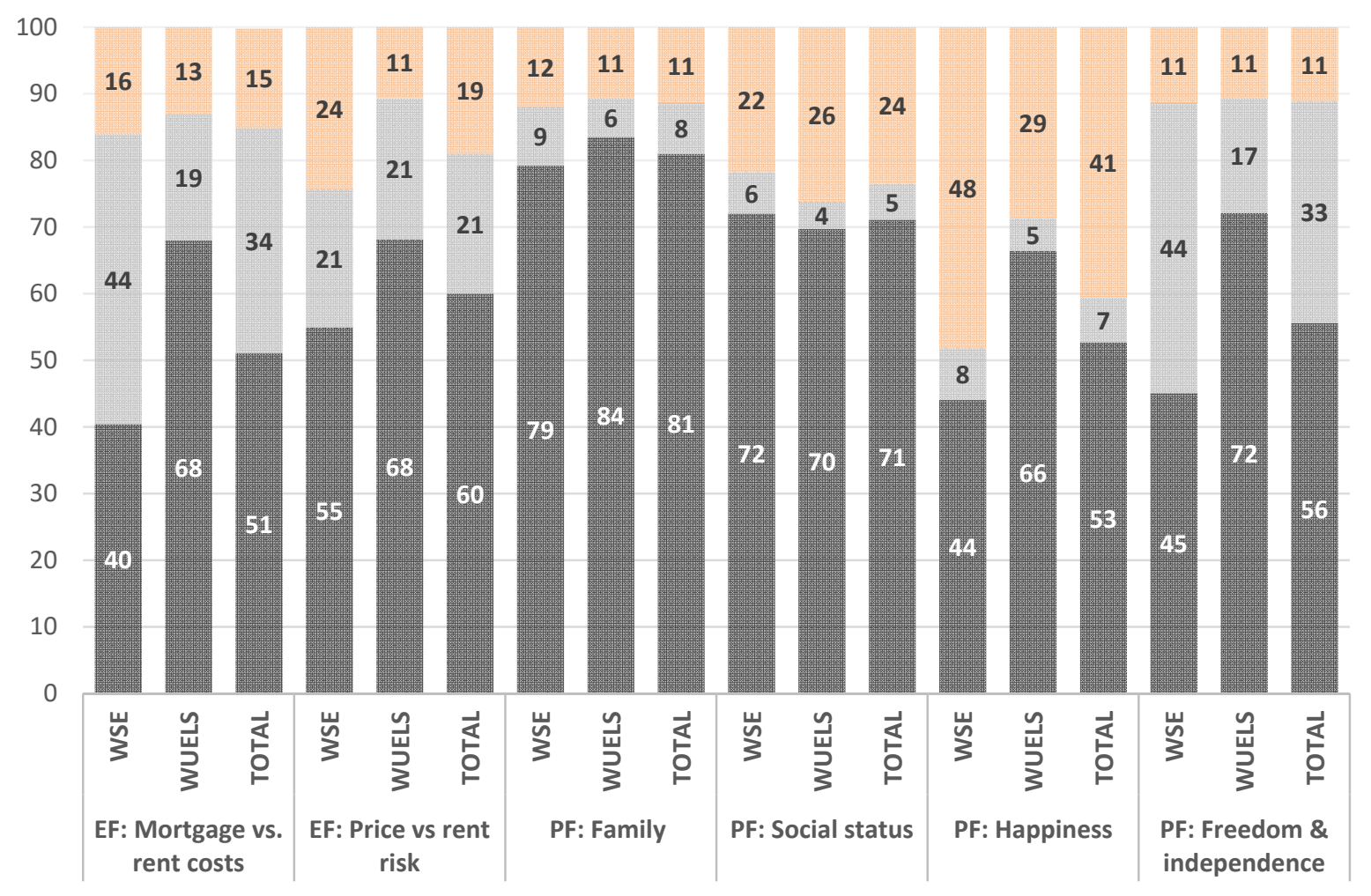

霮Buying Renting No opinion

Notes: EF - economic factor, PF - psychological factor, Price vs rent risk - risk of house price vs. rent price fluctuations.

Fig. 1. Economic and psychological factors and housing tenure preferences Source: The survey.

The first two panels of Figure 1 show that students generally prefer ownership to renting. In the case of relative costs, $51.1 \%$ of students pointed to owning, whereas $33.8 \%$ selected renting. However, the distribution of answers is visibly different between the universities: for the WUELS students, there is a much stronger perception that renting is costlier than paying mortgage than for the WSE students. In this respect, it can be noted that rent prices in Poland are relatively high in a European context, amounting to around $6 \%$ of house value per year (e.g. Łaszek et al. 2019). However, a simple comparison of rent price to mortgage instalments might be misleading as it does not take into account additional costs that need to be taken by owners, such as maintenance or insurance. This is probably the main reason why WSE students are more skeptical about the relative advantage of owning than the WUELS ones. When looking into the risk factor, house price fluctuations were perceived to be of lower importance than rental cost volatility (50.0\% of answers for owning versus $21.0 \%$ for renting). These answers might be partly influenced by the fact that, in Poland, there has been no significant decline in house prices, whereas rent prices have been gradually increasing over the last two decades (Easzek et al. 2019). This could, however, also be attributed to the fact that the private rental market is 
dominated by short-term lease contracts, which provide the tenant with virtually no protection against rent changes.

As regards non-financial factors, taking into account the results of Coolen et al (2002) and, above all, Ben-Shahar (2007), we selected the following psychological factors:

- family,

- social status,

- happiness,

- a sense of freedom and independence.

The distribution of answers presented in the right panels of Figure 1 shows that the most important psychological reason for owning is family ( $81.0 \%$ of answers for owning versus $7.2 \%$ for renting). The respondents do not consider renting as a viable alternative to ownership as a long-term solution to provide a good and secure place for a family. Ownership is also perceived as a factor that increases social status (72.5\% versus 5.1\%). In both cases the distribution of answers between the universities was generally the same. As regards happiness (52.7\% versus $6.7 \%)$, many students had no opinion. In this case, however, it can be noticed that for WUELS students owning a house was much more frequently associated with happiness (66.4\%) than for WSE ones (47.3\% and 39.3\%). These answers indicate that the comparison of both tenures is not only based on the relative level of rent and mortgage service costs, but also takes into account that owning provides additional value in the form of higher social status or happiness. This would explain why about one third of the students would decide to buy even if renting was cheaper. As regards the last psychological factor - freedom and independence - the distribution of answers is relatively mixed (55.6\% versus $33.3 \%)$. Moreover, there are the highest differences among the WSE and WUELS students in this case. It can be noted that, on the one hand, renting allows for higher residential and labor mobility (Barcelo, 2006, Caldera-Sanchez \& Andrews, 2011), but on the other hand, ownership gives more freedom in terms on how to arrange the interior of a house. It seems that the first factor is downplayed by WUELS students and much more appreciated by those attending WSE.

\subsection{Factors diminishing the comfort of renting}

In the previous subsection, we presented evidence that students prefer ownership to rental not only due to relative cost disadvantage but also due to non-financial factors. We also revealed that the perception of WUELS students about the relative advantages and disadvantages of both housing tenures differs from the perception of the WSE students. WSE students, who are equipped with sound economic education, seem to see less disadvantages of renting, both economic and psychological. To dig deeper into this topic, we asked a series of questions aimed at determining the most important reasons behind the discomfort of behind a tenant. The answers presented in Table 3 show that there are at least three kinds of such reasons.

First of all, tenants do "not feel at home". The respondents of the survey agree that tenants are too constrained when it comes to arranging the apartment $(76.0 \%)$ and that landlords inspect the apartment too often $(63.3 \%)$. For the WUELS students, these shares are even higher, amounting to $83.6 \%$ and $79.5 \%$, respectively. This points to the lack of professionalization of the rental market services. The main reason is that the rental sector is dominated by private landlords, and not institutional investors. In most cases, they are "incidental landlords: and not intentional business entrepreneurs (Priemus and Mandic 2000). This is confirmed by answers to the survey, which indicate that students would prefer to rent from institutional investors rather than from private landlords: $54.9 \%$ of respondents agree that the lack of institutional investors decreases the comfort of being a tenant.

The second group of reasons behind the discomfort of being a tenant are inefficient regulations. In brief, there are generally three types of rental contracts: (i.) open-ended, (ii.) temporary and (iii.) occasional. As regards the protection of tenants against eviction, types (i.) and (iii.) are corner solutions. In the case of the open-ended contract, tenants are strongly protected against eviction, especially families with children. Given the inefficiency of Polish courts, the time required to get rid of a "bad tenant" is relatively long and amounts to around 9 months. In turn, the occasional contract virtually does not protect tenants at all. They have to present the alternative place of residence to which they can be evicted. Moreover, signing this contract involves some bureaucracy, a visit to a notary for instance. For that reason, only a tiny fraction of landlords decide to sign type (i) or (iii) of 
contracts. The private rental market is dominated by temporary, short-term contracts. As regards rent controls, the level of rents can be freely negotiated between the landlord and tenant at the time of signing a contract. Moreover, the landlord may increase the rent once every six months, by giving one month's notice. This mixture of regulations makes it difficult to treat renting as a long-term and stable method of satisfying housing needs, where the price level of rent is predictable. This is confirmed by the responses to the survey, which indicate that the lack of protection against rent increases $(69.8 \%)$ as well as against eviction (55.2\%) decrease the comfort of being a tenant.

Table 3

Factors decreasing the comfort of being a tenant

\begin{tabular}{|c|c|c|c|}
\hline Sample & WSE & WUELS & TOTAL \\
\hline \multicolumn{4}{|c|}{ Tenants are too much constrained in arranging apartment } \\
\hline Decrease comfort & 71.0 & 83.6 & 76.0 \\
\hline Don't decrease comfort & 10.8 & 6.6 & 9.1 \\
\hline No opinion & 18.3 & 9.8 & 14.3 \\
\hline \multicolumn{4}{|c|}{ Landlords are inspecting the apartment too often } \\
\hline Decrease comfort & 52.7 & 79.5 & 63.3 \\
\hline Don't decrease comfort & 19.4 & 4.9 & 13.7 \\
\hline No opinion & 28.0 & 15.6 & 23.0 \\
\hline \multicolumn{4}{|c|}{ Lack of institutional investors } \\
\hline Decrease comfort & 46.8 & 67.2 & 54.9 \\
\hline Don't decrease comfort & 17.7 & 5.0 & 12.6 \\
\hline No opinion & 35.5 & 27.9 & 32.5 \\
\hline \multicolumn{4}{|c|}{ Tenants are not well protected against rent increases } \\
\hline Decrease comfort & 60.2 & 75.5 & 69.8 \\
\hline Don't decrease comfort & 14.0 & 3.2 & 9.7 \\
\hline No opinion & 19.9 & 21.3 & 30.5 \\
\hline \multicolumn{4}{|c|}{ Tenants are not well protected against eviction } \\
\hline Decrease comfort & 46.8 & 68.1 & 55.2 \\
\hline Don't decrease comfort & 18.8 & 6.6 & 14.0 \\
\hline No opinion & 34.4 & 25.4 & 30.8 \\
\hline \multicolumn{4}{|c|}{ Rents are too high (in comparison to mortgage instalments) } \\
\hline Decrease comfort & 50.5 & 74.6 & 60.0 \\
\hline Don't decrease comfort & 12.9 & 1.6 & 8.4 \\
\hline No opinion & 36.6 & 23.8 & 31.6 \\
\hline \multicolumn{4}{|c|}{ The offer of dwellings to rent is too scarce to meet preferences } \\
\hline Decrease comfort & 48.4 & 71.3 & 57.5 \\
\hline Don't decrease comfort & 21.0 & 2.4 & 13.6 \\
\hline No opinion & 30.6 & 26.2 & 28.9 \\
\hline Number of observations & 186 & 122 & 308 \\
\hline
\end{tabular}

Source: The survey.

Finally, it can be noted that a high level of rents $(60.0 \%)$ as well as a scarce offer of houses for rent $(57.5 \%)$ are also constraining the inclination to rent. These two factors, which are rather economic, can be explained by inefficient regulations, fiscal incentives towards ownership or the lack of public support for institutional investors to build houses to let. These topics are going to be discussed in the next section of the article.

\section{Discussion}

The results of the survey demonstrate that there are two main reasons behind the low size of the private rental housing sector in Poland: it is relatively expensive in comparison to owning and the housing satisfaction of tenants is lower than that of owners. In this section, we attempt to explain what kind of housing policy can promote the development of the rental market, among others by looking at 
solutions introduced in the Czech Republic, which is characterized by the highest share of private market tenants among post-communist countries (16.1\% in 2019). What is important, in 2007 the fraction of tenants in the Czech Republic was broadly comparable to other countries of the region and amounted to merely $4.8 \%$. We start by noting that, almost two decades ago, Priemus and Mandic (2000) indicated that "The policy context of rental housing (rent policy, fiscal policy, property rights) will have to change dramatically in Central and Eastern Europe before professional investors will want to put their money into housing there". It can be argued that the situation has not changed a lot since 2000. The review of rental market regulations across EU countries conducted in years 2012-2015 within the TenLaw project (Tenancy Law and Housing Policy in Multi-level Europe) shows that developers in Eastern European countries are building apartments primarily for sale and even in the case of there being unsold units, they are not interested in renting them. Consequently, the residential rental market is dominated by individual landlords, in many cases ones that inherited a dwelling or purchased it for children, and treat letting as a temporary activity. The landlord structure in the Czech Republic is different, with a larger importance of institutional investors. As described by Vobecká et al. (2014), their emergence might be explained by three factors:

1. tax conditions, which allow house depreciation to be deducted from rental income,

2. large scale of property restitution, which created professional landlords possessing all flats in residential buildings,

3. the entry of large institutional investors into the market within the privatization process.

The increase in the supply of private rental dwellings managed by institutional investors due to the above factors contributed to a decline in the costs of renting. In fact, data by Global Property Guide ${ }^{1}$ that show the gross rental yield in the Czech Republic to be $3.14 \%$ (compared to $5.50 \%$ in Poland) is the lowest of Eastern European countries, and comparable to Germany or Switzerland. A big question is whether the emergence of professional investors increased the quality of rental services and diminished the "disutility of being a tenant" described in the previous section.

Let us now focus on regulations that constrain or stimulate demand for long-term rental. We start by looking at the regulations protecting tenants against eviction. It might be argued that good regulations satisfy two conditions. First, they protect landlords against bad tenants, hence stimulate the supply of rental housing by decreasing the risk profile of buy-to-let investment. Secondly, they provide good tenants with a sense of security that the contract is long-lasting, hence enhance demand for long-term rental. Unfortunately, in Poland, there are solutions that satisfy only one of the above conditions. Within the regular, open-ended contract, landlords are not well protected against bad tenants. The termination of such a contract by a landlord may occur one month in advance if the tenant has not made any rent payment for at least three full payment periods. Moreover, the eviction verdicts cannot be executed between 1 November and 31 March of the following year, unless the evicted tenant is guaranteed an alternative place of residence. Taking into account the inefficiency of the courts, it is possible that the period between a tenant ceasing to make payments and the moment of eviction can amount to one year. In turn, the two alternative contracts (temporary and occasional), as indicated by their names, are designed for a short-term rental. They are not suited for tenants interested in long-term rental, for whom the lack of protection against eviction seriously decreases the attractiveness of renting in comparison to owning (Table 3). In the Czech Republic the situation is somewhat more balanced for open-ended contract. The Civil Code provisions imply a three-month notice period of terminating the contract for both sides. The tenant has the right to terminate the contract unilaterally without giving any reasons, whereas the landlord may give notice of tenancy termination only due to the reasons enumerated by the law. In cases with a relevant reason for tenancy termination by the landlord, e.g. non-payment of rent or serious violation of good manners, the landlord may evict the "bad tenant" without court approval. However, new rental contracts are usually temporary ones (typically for one year) and, when the contract terminates, the tenant is evicted automatically with no reason required. As a result, as claimed by Lux and Sunega (2010a), eviction law constrains the long-term demand for private rental housing also in the Czech Republic.

As regards regulations related to rent control, tenants in Poland are protected against rent increases under an open-ended contract. Rent increases can be justified predominantly by the general increase in prices as measured in headline inflation. Rents can be also increased freely to a level not

${ }^{1}$ https://www.globalpropertyguide.com/Europe/rent-yields, data from 7 July 2020. 
exceeding 3\% of the value of the rented apartment, which is currently well below the market level of rents. A change in the level of rents may occur every half a year, subject to a minimum 3-month notice period. In case the tenant does not accept the new financial terms, he or she is entitled ask the court to decide whether the rent increase is justified. As a result, the risk of rent increase within the openended contracts is low. In the Czech Republic, the Civil Code specifies formal and contextual conditions of rent increases within open-ended contracts. The landlord may suggest, in a written form, a rent increase up to a level comparable to the usual rent in a certain location. This, however, is possible if a suggested increase is not higher than $20 \%$ for the 3 -year period. As a result, it might be argued that this solution limits rent increase risk, and hence does not constitute constraint to longterm demand for rental. The problem, however, is that most new rental contracts in both countries are temporary ones, in which the level of rent is renegotiated each time a new contract is signed (usually each year). Given that the law does not impose any limits on the initial level of rent, the risk of increased rent for such contracts is very high, which diminish the demand for long-term rental.

The other reason behind the relative attractiveness of ownership in comparison to renting in Poland is that fiscal policy is not neutral. First, income from renting is subject to taxation, whereas imputed rent for homeowners is tax-free. Institutional investors have to pay a 19\% CIT tax on profits from rental services, whereas individual landlords can choose between PIT rate on profits or $8.5 \%$ turnover tax. Moreover, there have been two large programs subsidizing mortgages in the last decade (already mentioned "Rodzina na Swoim" and "Mieszkanie dla Młodych") and no big programs subsidizing renting. It can, therefore, be concluded that fiscal incentives were clearly directed towards owning. In the Czech Republic the fiscal policy is more ambiguous. On the one hand, income from renting is also taxed and there is no tax on imputed rents. The flat tax rate is $15 \%$ but, given that landlords might by default deduct $30 \%$ of the gross rent to account for maintenance costs, the effective tax rate is $10.5 \%$. On the other hand, there are subsidies oriented towards developing the rental market. Within "Státní fond rozvoje bydlení" (State Housing Development Fund), a fund created within the "Housing Policy Concept for the Czech Republic till 2020" approved in 2011, there are two programs subsidizing build-to-let investments. The first one (the Záruk Program) relies on government guarantees for loans that are targeted to build rental housing. The second (the Výstavby Program) is targeted to construct rental apartments for defined groups of people, seniors or persons whose dwelling was destroyed by a natural disaster for instance. It can be noted that, from an architectural perspective, housing policy focused on the development of the institutional rental market should be aware that build-to-let activity is well suited to meeting specific housing needs of different social groups. For example, other spatial solutions will be applied in buildings for students, families with children or the elderly. This applies to architectural solutions for the dwellings themselves (number and size of apartments) as well as the type of shared space (gyms, playgrounds, laundries) or facilities in the ground floor (clinics, shops, kindergarten, clubs, home care). In this respect, the above-mentioned Výstavby Program is an example of good practice.

The short comparison of housing policies in Poland and the Czech Republic presented above indicates that the private rental market is more developed in the latter economy, predominantly due to solutions that promote the supply of rental housing. This has allowed the level of rents to drop to affordable levels, making renting a financially attractive alternative to ownership. In both countries, however, a strong preference of ownership due to non-financial factors prevails. As regards the demand for long-term rental, it is seriously constrained by the duality of the rental market. Even though tenants are protected against eviction and rent increases within the open-ended contract, new rental contracts are predominantly temporary, in which the level of protection is rather low. As a result, the rental market is treated rather as a temporary method of satisfying housing needs. Finally, it should be noted that tax policy in both countries favors owning to renting.

\section{Conclusions}

In Poland, only a small percentage of households decide to satisfy housing needs through renting a dwelling on the private market. These are mainly unmarried young adults, for instance university students, who treat renting as a transitional stage and not as a long-term solution. Our study showed that this high level of homeownership results from the financial disadvantages of renting, but also social, cultural and psychological factors. The respondents to the survey conducted among students from two Polish universities perceive ownership not only as a cheaper form of satisfying housing needs, but also as the only method of ensuring a safe place for a family or improving social status. The 
survey also indicates that the quality of rental services in Poland is low. Factors such as the lack of possibility to arrange an apartment or frequent inspections by a landlord seriously decrease the satisfaction from living in a rented apartment. Overall, the conducted analyses point to clear preferences of Poles towards ownership.

Apart from individual preferences, we also argued that, at the country level, the housing policy also limits the development of the rental market, though sometimes unintentionally. The most important constraint to demand for long-term renal is that regulations excessively protecting tenants within open-ended contracts have led (perversely) to an equilibrium in which new tenants are protected very little, as the market is dominated by alternative, temporary contracts. On top of this, taxes also favor ownership. Housing services for owners are not taxed, whereas renting is subject to income tax. Additionally, there were two big programs subsidizing mortgages in Poland, with no significant programs subsidizing build-to-rent investments. This is the biggest difference between Poland and the Czech Republic. In the latter country, policies promoting the supply of residential rental housing facilitated an increase in the renal market share.

On the basis of the above results, one can put forward a number of recommendations for housing policy aimed at developing the residential rental market. The most important challenge relates to the design of the rental contract. The currently observed duality (open-ended versus temporary contracts) could be replaced by a single, open-ended contract, which would ensure a sense of security for good tenants and, at the same time, provide protection to landlords against bad tenants. While setting the level of tenant protection against eviction and rent increases, it can be assumed that, basing on the German experience, the expected contract duration is ten years. The second challenge is related to the currently observed low quality of renting services. In this respect encouraging institutional investors with programs that improve the expected return and risk profile of build-to-rent investment seems to be a good solution. The complementary policies would be to assist associations gathering or real estate agencies servicing individual landlords in promoting good practices. Thirdly, reducing the relative cost of renting by introducing neutral fiscal solutions would also help. Finally, it is worth mentioning that the decision of whether to own or rent a house often comes from flawed economic reasoning. Consequently, better economic education on the relative advantages of both housing tenures could probably increase the demand for renting.

\section{Acknowledgements}

This project was financed by the National Science Centre (Narodowe Centrum Nauki), grant number 2014/15/B/HS4/01382.

\section{References}

Barceló C. (2006). Housing Tenure and Labour Mobility: A Comparison Across European Countries. Banco de Espana Documentos de Trabajo 0603.

Ben-Shahar, D. (2007). Tenure choice in the housing market: Psychological versus economic factors. Environment and Behavior, 39(6), 841-858. https://doi.org/10.1177/0013916506297829

Bourassa, S. C. (1995). A Model of Housing Tenure Choice in Australia. Journal of Urban Economics, 37(2), 161-175. https://doi.org/10.1006/juec.1995.1009

Caldera-Sánchez, A., \& Andrews, D. (2011). To Move or not to Move: What Drives Residential Mobility Rates in the OECD? OECD Economics Department Working Papers 846.

Coolen, H., Boelhouwer, P., \& van Driel, K. (2002). Values and goals as determinants of intended tenure choice. Journal of Housing and the Built Environment, 17(3), 215-236. https://doi.org/10.1023/A:1020212400551

Diaz-Serrano, L. (2009). Disentangling the housing satisfaction puzzle: Does homeownership really matter? Journal of Economic Psychology, 30(5), 745-755. https://doi.org/10.1016/i.joep.2009.06.006

Drew, R. B., \& Herbert, C. E. (2013). Postrecession Drivers of Preferences for Homeownership. Housing Policy Debate, 23(4), 666-687. https:// doi.org/10.1080/10511482.2013.823880

Elsinga, M., \& Hoekstra, J. (2005). Homeownership and housing satisfaction. Journal of Housing and the Built Environment, 20(4), 401-424. https://doi.org/10.1007/s10901-005-9023-4

Henderson, J. V., \& Ioannides, Y. M. (1983). A model of housing tenure choice. The American Economic Review, 73(1), 98-113. 
Haurin, D. R., Hendershott, P. H., \& Kim, D. (1993). The impact of real rents and wages on household formation. The Review of Economics and Statistics, 75(2), 284-293. https://doi.org/10.2307/2109434

Lux, M., \& Sunega, P. (2010a). Private rental housing in the Czech Republic: Growth and...? Sociologický časopis. Sociologicky Casopis, $\quad$ 46(3), 349-374. https://doi.org/10.13060/00380288.2010.46.3.02

Lux, M., \& Sunega, P. (2010b). The future of housing systems after the transition-The case of the Czech Republic. Communist and Post-Communist Studies, 43(2), 221-231. https://doi.org/10.1016/j.postcomstud.2010.04.001

Lux, M., \& Sunega, P. (2014). Public Housing in the Post-Socialist States of Central and Eastern Europe: Decline and an Open Future. Housing Studies, 29(4), 501-519. https://doi.org/10.1080/02673037.2013.875986

Łaszek, J., Augustyniak, H., Gałaszewska, K., Olszewski, K., Waszczuk, J., \& Zaczek, M. (2019). Information on home prices and the situation in the housing and commercial real estate market in Poland in 2019 Q2. National Bank of Poland.

Muzioł-Węcławowicz, A. (2013). Poland: Old problems and new dilemmas. Chapter 10 in. Lux M., Hegedus J., Teller N. (Eds.) Social housing in transition countries, Routledge, p. 195-209.

Palicki, S. (2020). Housing Preferences in Various Stages of the Human Life Cycle. Real Estate Management and Valuation, 28(1), 91-99. https:// doi.org/10.2478/remav-2020-0008

Priemus, H., \& Mandic, S. (2000). Rental housing in central and Eastern Europe as no man's land. Journal of Housing and the Built Environment, 15(3), 205-215. https://doi.org/10.1023/A:1010186618204

Rubaszek, M. (2019). Private rental housing market underdevelopment: Life cycle model simulations for Poland. Baltic Journal of Economics, 19(2), 334-358. https://doi.org/10.1080/1406099X.2019.1679558

Rubaszek, M., \& Czerniak, A. (2017). Preferencje Polaków dotyczące struktury własnościowej mieszkań: Opis wyników ankiety. Bank i Kredyt, 48(2), 197-234.

Rubaszek, M., \& Rubio, M. (2020). Does rental housing market stabilize the economy? A micro and macro perspective. Empirical Economics, 59(1), 233-257. https://doi.org/10.1007/s00181-019-01638$\underline{z}$

Sinai, T., \& Souleles, N. S. (2005). Owner-occupied housing as a hedge against rent risk. The Quarterly Journal of Economics, 120(2), 763-789.

Vobecká, J., Kostelecký, T., \& Lux, M. (2014). Rental Housing for Young Households in the Czech Republic: Perceptions, Priorities and Possible Solutions. Sociologicky Casopis, 50(3), 365-390. https://doi.org/10.13060/00380288.2014.50.3.102

Źróbek-Różańska, A. (2019). Depopulation of Cities and Housing Decisions of University Graduates. Real Estate Management and Valuation, 27(4), 105-113. https://doi.org/10.2478/remav-2019-0040

Źróbek-Różańska, A., \& Szulc, L. (2018). Over a Million Student Tenants in Poland. Analysis of Preferences. Real Estate Management and Valuation, 26(2), 104-113. https://doi.org/10.2478/remav$\underline{2018-0020}$

\section{Annex. The survey questionnaire}

1. Year of birth

2. Sex

3. Marital status

4. Employment status

5. Observing the current economic situation in Poland, please specify the economic situation of your household on a scale of 1 to 10 (1-very bad, 10-very good)

6. Tenure status of currently inhabited residence

7. The size of currently inhabited residence

8. In comparison to the current place of your residence you grew up in: different country/ different town / the same town

9. Since when do you live in your current address?

10. When do you expect to change your residence

11. The most likely tenure status of new residence in case of moving

12. A sentence closer to your opinion: 
a. Buying a house makes more sense because you're protected against rent increases and it is a good investment decision over the life cycle

b. Renting makes more sense because it enables flexibility and financial liquidity and protects you against house price declines and, considering financial considerations, is a better deal than owning

13.A choice in case of no funds to buy a dwelling
a. Buying despite the burden of a mortgage
b. Renting
c. Don't know

14. Do you agree with the statement:

Buying a house is financially better than renting it because after repaying the mortgage you are left with a house and after paying rents you are left with nothing

15. Please indicate which sentences you agree/disagree with:

a. Paying rent is a waste of money

b. I would buy a house with a mortgage even if it is more expensive than renting

16. Ignoring other factors, please indicate if you prefer renting or buying with a mortgage:
a. The burden of paying mortgage instalments vs. the cost of renting
b. Risk of house price vs. rent price fluctuations
c. Transaction costs
d. Taxes

17. Ignoring other factors, please indicate if you prefer renting or buying with a mortgage:
a. Social status
b. Sense of freedom and independence
c. Well-being
d. Family
e. Happiness

18. Please indicate, which factors are decreasing the comfort of renting in Poland?
a. Tenants are not well protected against rent increases
b. Tenants are too much constrained in decorating and modifying the apartment
c. Landlords are inspecting the apartment too often (invigilation in private life)
d. Tenants are not well protected against eviction
e. Rents are too high in comparison to mortgage instalment
f. The lack of institutional landlords
g. The offer of dwellings to rent is too scarce to meet preferences 